\title{
The 2007 International Consensus Conference Definition in ventilated pediatric patients
}

\author{
Alejandra Retta ${ }^{1}$, Ezequiel Monteverde ${ }^{1}$, Analía Fernández ${ }^{2}$, Silvio Torres ${ }^{3}$, Virginia \\ Altuna $^{1}$, Alejandro Siaba Serrate ${ }^{3}$, and Rossana Poterala ${ }^{4}$ \\ ${ }^{1}$ El Hospital de Niños Ricardo Gutierrez \\ ${ }^{2}$ Hospital General de Agudos Carlos G Durand \\ ${ }^{3}$ Hospital Universitario Austral \\ ${ }^{4}$ Sanatorio Anchorena
}

November 7, 2021

\begin{abstract}
Background The Task Force classification (TFC) identifies weaning from mechanical ventilation (MV) in adults as: simple (SW), difficult (DW) and prolonged (PW). The usefulness of this classification is unknown in pediatric patients. Methods Prospective, descriptive, multicenter study in 29 pediatric intensive care units from Argentina during a three-month period including all admitted patients who required MV and met weaning criteria. The evolution of these patients was analyzed according to TFC. Results 474 patients were included, $454(95.8 \%)$ of whom were successfully extubated. Eighty percent (n=370) were extubated after the first attempt and classified as SW, 84 (18,2\%) were DW and only 7 (1,5\%) faced a PW. Successful extubation on the first trial was $77.9 \%(\mathrm{n}=356)$ and for subsequent trials, $56.7 \%, 64.5 \%$ and $66.7 \%$. The duration of MV (in days) by group was [median (interquartile range)]: 5.4 (2.8-9.7) (SW), 10.6 (7.7-18.8) (DW) and 27.4 (15.1-28.4) (PW). Fourteen patients underwent tracheostomy without any weaning attempt, 3 patients were on MV at the end of the study and 3 patients died without any attempt. The only variable associated with PW and DW (as a single group, with SW as reference) in multivariable analysis was ventilator-associated pneumonia (OR 2.58, 95\%CI 1.01-6.11). Conclusions We observed a low prevalence of PW. Patients with PW and DW showed no significant differences from patients with SW, albeit a higher incidence of VAP.
\end{abstract}

\section{Hosted file}

Main-document-and-Ref--3-.docx available at https://authorea.com/users/430917/articles/ 544510-the-2007-international-consensus-conference-definition-in-ventilated-pediatricpatients

\section{Hosted file}

table 1.docx available at https://authorea.com/users/430917/articles/544510-the-2007international-consensus-conference-definition-in-ventilated-pediatric-patients

\section{Hosted file}

table 2.docx available at https://authorea.com/users/430917/articles/544510-the-2007international-consensus-conference-definition-in-ventilated-pediatric-patients

\section{Hosted file}

table 3.docx available at https://authorea.com/users/430917/articles/544510-the-2007international-consensus-conference-definition-in-ventilated-pediatric-patients 

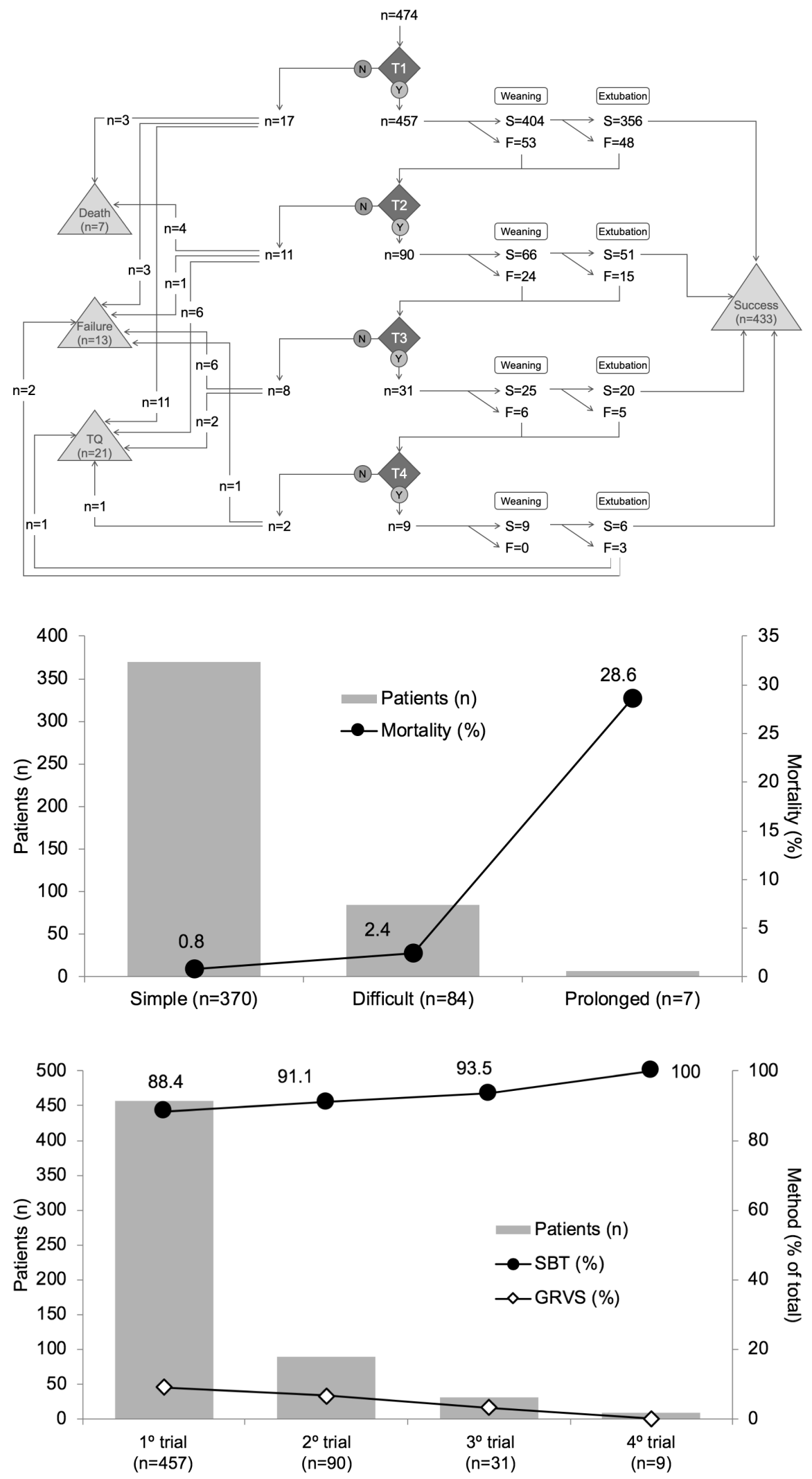